\title{
Injury, regeneration and growth of Caribbean reef corals after a major oil spill in Panama
}

\author{
Héctor M. Guzmán ${ }^{1}$, Kathryn A. Burns ${ }^{2}$, Jeremy B. C. Jackson ${ }^{1}$ \\ ${ }^{1}$ Smithsonian Tropical Research Institute, Box 2072, Balboa, Republic of Panama \\ ${ }^{2}$ Bermuda Biological Station for Research, Inc., 17 Biological Lane, Ferry Reach, GE 01, Bermuda
}

\begin{abstract}
We studied effects of a major oil spill in Panama on injury, regeneration and growth of subtidal reef corals over 5 yr. Corals exhibited much higher levels of injury, faster regeneration rates and slower growth on heavily oiled reefs. Concentrations of hydrocarbons in reef sediments were significantly positively correlated with amounts of coral injury and significantly negatively correlated with coral growth. The probable cause of persistently high levels of coral injury is chronic exposure to sediments mixed with partially degraded oil that are exported from mangroves onto adjacent reefs. Injury apparently results in a reallocation of resources to regeneration and consequently decreased investment in fecundity and growth. There was no evidence of coral recovery 5 yr after the oil spill
\end{abstract}

KEY WORDS: Chronic contamination - Coral reef H Hydrocarbons - Oil spill - Recovery · Stress . Sublethal effects

\section{INTRODUCTION}

Patches of tissue of colonial animals like reef corals are commonly injured by natural enemies or physical processes (Loya 1976, Bak et al. 1977, Bak \& Stewardvan Es 1980, Palumbi \& Jackson 1982, Jackson 1983, Wahle 1983). Injuries expose the coral skeleton which is soon colonized and overgrown by algae and other organisms. Eventually the coral may regenerate the injury by overgrowing these invaders, or the lesion may persist and expand. In either case, regeneration of damaged tissue may slow down with time so that net coral growth is reduced (Bak 1983). A similar response is expected for reef corals exposed to chronic pollution.

In April 1986 at least 60000 to 100000 barrels of medium weight crude oil spilled from a ruptured storage tank into Bahía Las Minas on the central Caribbean coast of Panama (Fig. 1; Jackson et al. 1989). Intertidal mangroves, seagrass beds and reef flats along most of the $82 \mathrm{~km}$ of coast within the bay were covered by oil and soon died. Subtidal corals and the fauna of subtidal seagrasses also died (Guzmán et al. 1991, Marshall et al. 1993). Much oil soaked into organically rich sediments of the mangroves and seagrass beds. These sediments have remained reservoirs of oil and a source of chronic reoiling of the coast since the spill (Burns et al. 1993). Oil was also found in sediments of subtidal coral reefs and within the tissues of surviving corals (Burns \& Knap 1989).

Here we present results of a 5 yr study of sublethal responses of surviving colonies of the 4 most common massive species of reef-building corals in relation to patterns of sedimentation and petroleum contamination. Extensive, chronic effects on vital processes were still clearly apparent after $5 \mathrm{yr}$.

\section{MATERIALS AND METHODS}

Reeis and species studied. The 12 reefs studied include 6 that were visually classified as heavily oiled [Punta Muerto (PM), Payardi North (PAYN), Payardi West (PAYW), Largo Remo 1 (LRE1), Largo Remo 2 (LRE2), Galeta Channel (GALC)], 2 moderately oiled [Naranjos South (NARS), Margarita 3 (MAR3)], and 4 unoiled [Juan Gallegos (JUG), Palina West (PALW), Dos Marias (DMA), Doncella Reef (DONR)] in 1986 (Burns \& Knap 1989, Jackson et al. 1989, Guzmán et al. 1991). For simplicity of analysis, biological observations from the 2 moderately oiled reefs were only used in conjunction with the hydrocarbon data. In all other cases, we compared just the 4 unoiled to the 6 heavily oiled reefs. 


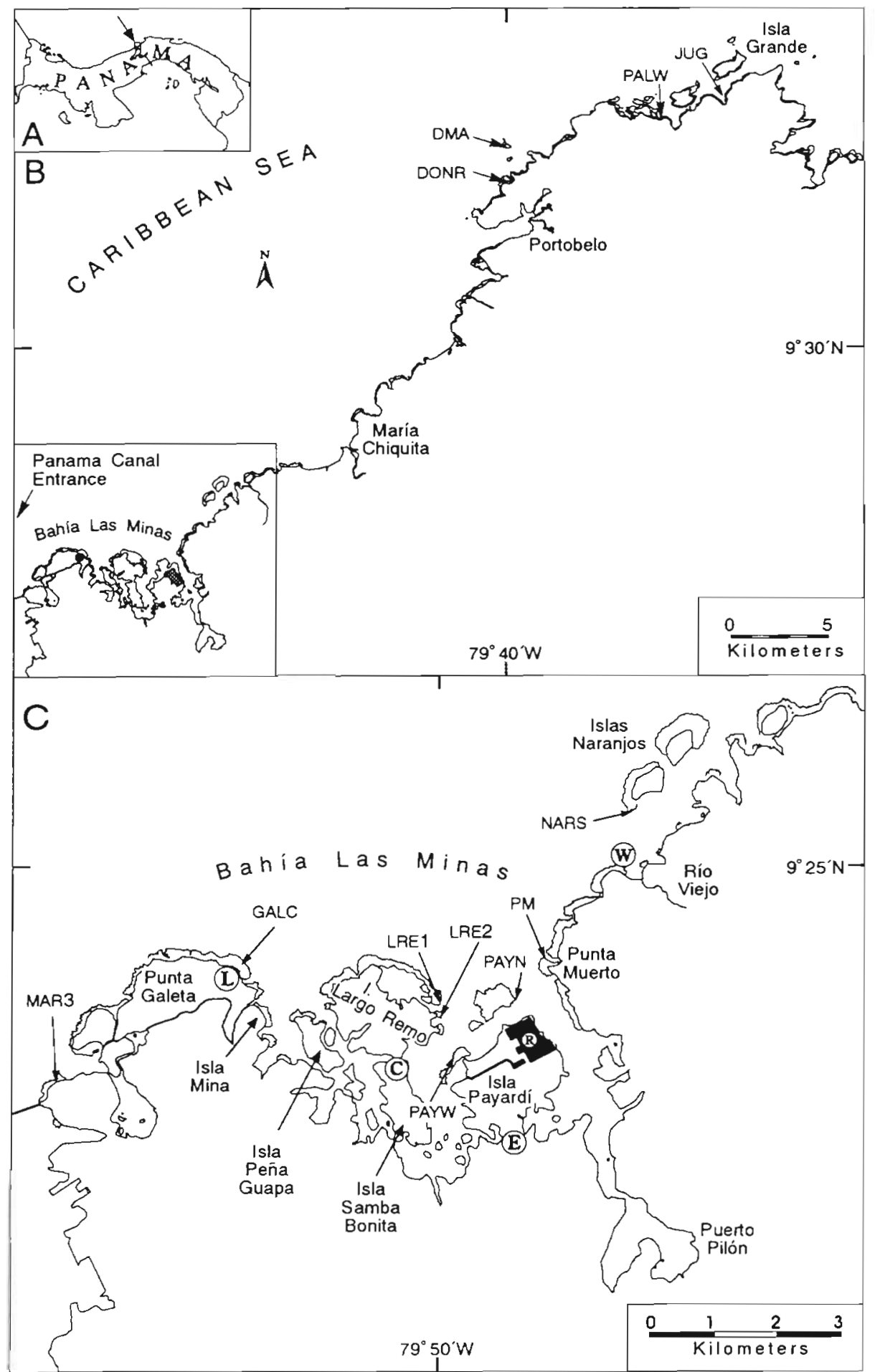

Fig. 1. Region off the Caribbean coast of Panama affected by the 1986 oil spill shown as increasing enlargements ( $A$ to $C$ ). (A) Location within Panama. (B) Unoiled reefs near Portobelo and Isla Grande. (C) Heavily oiled and moderately oiled reefs (see Table 1 for abbreviations). L: Galeta Marine Laboratory: C: cement factory; E: electrical power plant; R: refinery where the 1986 oil spill occurred; W: location of the stern section of the tanker 'Witwater' that spilled oil in 1968

We studied only massive species because almost all branching corals were killed by the oil spill (Guzmán et al. 1991). The species are: Siderastrea siderea (Ellis \& Solander), Porites astreoides Lamarck, Diploria clivosa (Ellis \& Solander), and Diploria strigosa (Dana). Not all of these were examined in every aspect of the study.
Hydrocarbons. In addition to the initial visual assessment (Jackson et al. 1989), we recorded the presence or absence of oil slicks over all 12 reefs from August 1987 to December 1991 (Guzmán et al. 1991). Most slicks were observed emanating from mangroves and the landfill beneath the refinery. However, during 
December 1988 and June 1990, an unestimated amount of diesel fuel spilled into Bahía Las Minas from a storage tank at an electrical generating station about $1 \mathrm{~km}$ from the refinery (Fig. 1). Three of our study reefs (LRE2, PAYW, \& PAYN) may have been affected by these additional spills.

Reef sediments and corals were collected for hydrocarbon analyses during August-September 1986 (Burns \& Knap 1989), December 1988 to March 1989 and July 1990 from among the same 12 reefs where we observed injury, regeneration and growth. No oil slicks were observed over the reefs when the hydrocarbon samples were collected. Corals were collected by divers at 1.5 to $6 \mathrm{~m}$ depth using a hammer and chisel, sealed on the boat with solvent-washed aluminum foil, labelled, and packed in polyethylene bags, taking care not to touch the living portion of the colony. Surface reef sediments were collected by divers using solventcleansed glass jars and sealed with screw-cap lids lined with foil. Samples were transported on ice to the laboratory where all were frozen at $-20^{\circ} \mathrm{C}$. Corals were thawed, and tissue was scraped from the skeletons with clean stainless steel scalpels. This technique yields good tissue recovery, but does not allow accurate determination of the wet weight of tissues due to skeletal inclusions. Afterwards, samples were packed on ice and flown to the Bermuda Biological Station for Research for chemical analysis.

Analytical methods developed for this study followed guidelines published by IOC/UNEP/IAEA (1991), and which have been presented in detail elsewhere (Burns \& Knap 1989, Burns 1993a, b). Two methods were used: (1) ultraviolet fluorescence spectroscopy (UVF) which is selectively sensitive to the aromatic hydrocarbons and their derivatives, and (2) flame ionization gas chromatography (GC) which is less specific but provides a more quantitative estimate of the total hydrocarbons in the $\mathrm{C}_{14}$ to $\mathrm{C}_{34}$ range. Coral samples were extracted in a Soxhlet apparatus by a hydrolysis procedure in which separate subsamples of the homogenized tissues were sonicated with $\mathrm{MeCl}_{2}$ for determination of lipid (defined as total extractable organic matter, EOM). Sediments were extracted with $\mathrm{MeCl}_{2}$ using sonication. All extracts were screened by UVF analysis. This procedure provided the data needed for replication for dose-response studies. Correlations were then established between UVF and GC estimates of oil content which was estimated as the total resolved plus unresolved (URE) hydrocarbon signal. Obvious biogenic hydrocarbons were excluded from quantification of oil content. Tissue extracts always required precleaning by adsorption chromotography before UVF analysis; sediments were fractionated only before GC analysis. Units for oil content are $\mu \mathrm{g}$ oil per mg EOM for coral tissues and $\mu \mathrm{g}$ per g dry wt for sediments.
Sedimentation. Amounts of suspended and resuspended sediments were measured monthly from October 1987 until December 1991 on all reefs but LRE1, weather permitting. Suspended sediments were determined by filtration (Cortés \& Risk 1985, Tomascik \& Sander 1985). Six replicate 1 l samples of seawater were collected at each reef. Samples were filtered using preweighed $0.45 \mu \mathrm{m}$ Millipore filters. A few drops of sodium azide $\left(\mathrm{NaN}_{3}\right)$ were used to poison the samples to prevent decomposition of organic matter. Filters were oven-dried at $45^{\circ} \mathrm{C}$ for $24 \mathrm{~h}$, cooled, and reweighed to the nearest $0.01 \mathrm{mg}$. Resuspended sediments were sampled using 6 sediment traps per reef (Cortés \& Risk 1985). The traps were constructed of PVC pipe $8 \times 24 \mathrm{~cm}$ (height: width ratio of 3), and were set on iron stakes with the opening $20 \mathrm{~cm}$ above the bottom at 1 to $3 \mathrm{~m}$ depth. Traps were collected 1 to $5 \mathrm{~d}$ after placement on reefs and trapped sediments recovered by filtration onto Whatman no. 1, $12.5 \mathrm{~cm}$ filter paper. Samples were then processed following the same protocol described for suspended sediments.

Injury. Quarterly surveys of recent injuries to all 4 species were made on all 12 reefs from August 1986 to March 1991 (Fig. 1; Guzmán et al. 1991). Recent injuries were inferred wherever bare white skeleton was exposed or only lightly overgrown by filamentous algae that characteristically settle within a few days of injury (Bak et al. 1977). At each census, 2 haphazardly placed $50 \times 2 \mathrm{~m}$ belt transects were run on each reef parallel to the reef crest: one between 0.5 and $1 \mathrm{~m}$ depth, the other between $>1$ and $2 \mathrm{~m}$ depth. The 2 transects were a minimum of $10 \mathrm{~m}$ apart, depending on the horizontal profile of the reef. All colonies of the 4 species were counted and examined for presence of injuries.

Regeneration. Recovery of experimentally injured corals was measured based on procedures used previously for different species (Bak et al. 1977). An artificial injury of $5.7 \mathrm{~cm}^{2}$ was inflicted on each colony by blasting the colony surface with compressed air. The resulting lesion closely resembles natural lesions caused by disease or bleaching. Photographs or video films were taken of each lesion just after it was made and at the end of the experiment 12 to 22 mo later. Images were analyzed using a Sigma-Scan digitizing tablet. The experiment was done twice on 2 heavily oiled reefs (LRE2, PAYN) and 2 unoiled reefs (PALW, JUG) at $1 \mathrm{~m}$ depth, using 5 replicate colonies per species per reef. Colony diameter was 20 to $25 \mathrm{~cm}$ for Porites astreoides and 60 to $70 \mathrm{~cm}$ for the 3 other species. The first experiment was run from September 1988 to October 1989 ( $P$. astreoides and Siderastrea siderea only) and the second from November 1990 to September 1992 (all 4 species). 
A third experiment to test whether regeneration rate was environmentally or genetically determined was made using colonies transplanted between an oiled reef (LRE2) and an unoiled reef (JUG). Five colonies of each of the 4 species were collected, transported and cemented to the reef framework from one reef to the other and vice versa, all within $3 \mathrm{~h}$.

Growth. Corals were collected from the same 10 reefs to compare growth 3 yr before and 3 yr after the oil spill. Nine small ( $<30 \mathrm{~cm}$ diameter) colonies each of Siderastrea siderea and Porites astreoides were collected from 1.5 to $3 \mathrm{~m}$ depth at each reef in late 1988 and 1989. Colonies were rinsed with fresh water, dried, and slabs 5 to $7 \mathrm{~mm}$ thick cut parallel to the axis of growth using a rock saw. The coral slabs were $\mathrm{x}$-rayed and radiographic prints made on highcontrast paper. Only 86 of 90 S. siderea and 61 of $90 P$. astreoides showed bands clear enough for measurement. Band widths were measured using a fine ruler (resolution $0.5 \mathrm{~mm}$ ) along a single transect overlying the axis of maximum growth. Further details of growth measurements are presented elsewhere (Guzmán et al. 1991).

Statistical design and analysis. The statistical design depended on the kinds of biological data available before the spill and observations made soon afterwards that helped to define the spatial scale of effects. We used simple 'before and after' comparisons of coral growth preserved in coral skeletons (main sequence no. 1 of Green 1979). However, there were no quantitative data prior to the oil spill of injury or regeneration, so we compared these parameters between oiled and unoiled reefs after the spill, wherein effects must be defined from the spatial pattern of change alone (main sequence no. 4 of Green 1979). In either case, we used repeated-measures ANOVA with individual reefs as replicates for each treatment (oiled and unoiled). Repeated measures analysis is necessary because all observations to test for biological effects involve repeated observations of the same corals or reefs (Underwood 1981, Hand \& Taylor 1987).

Statistical analyses of injury, growth and sedimentation were done using BMDP (Dixon et al. 1990). Variation in these parameters was evaluated by repeatedmeasures ANOVA with amount of oiling and depth (the latter only for injury) as between-factor variables and time of census as a within-factor variable. The time variable was scored as five 1 yr periods comprising every 3 to 4 censuses (August-September to MayJune of each year) for injury data and up to 12 monthly observations of sedimentation (usually less because of seasonally bad weather for sampling). In cases of significant interactions (oil $x$ time, oil $\times$ depth, depth $x$ time), differences were examined at levels of 1 factor at each level of the other factor, and vice versa.

BMDP 5V was used when unbalanced repeatedmeasures ANOVAs and contrast analyses were required because of missing observations in the repeated measures factor. The $5 \mathrm{~V}$ program uses maximumlikelihood criteria and provides a greater choice of covariance structure. The type of structure (compound symmetry or unstructured, fully parameterized covariance matrix) was chosen using the maximum Akaike's Information Criterion (AIC) value (Schluchter 1990).

Table 1. Percentage of days when oil slicks were observed above the study reefs off the Caribbean coast of Panama from August 1987 to December 1992. Numbers of observations are in parentheses. Reefs are listed from east to west within each category of oiling. U: unoiled; M: moderately oiled; H: heavily oiled

\begin{tabular}{|c|c|c|c|c|c|c|c|}
\hline \multirow{2}{*}{ No. } & \multirow{2}{*}{ Reef } & \multirow{2}{*}{ Oiling } & \multicolumn{5}{|c|}{ Percent days with oil slicks ${ }^{a}$} \\
\hline & & & 1987 & 1988 & 1989 & 1990 & 1991 \\
\hline 1 & Juan Gallegos (JUG) & $U$ & $17(6)^{\mathrm{b}}$ & $0(18)$ & $0(31)$ & $0(41)$ & $0 \quad(24)$ \\
\hline 2 & Palina West (PALW) & $\mathrm{U}$ & $0 \quad(7)$ & $0(18)$ & $0 \quad(30)$ & $0(37)$ & $4(26)^{c}$ \\
\hline 3 & Dos Marias (DMA) & U & $0 \quad(6)$ & $0(16)$ & $0(26)$ & $0(28)$ & $0(27)$ \\
\hline 4 & Doncella Reef (DONR) & $\mathrm{U}$ & $0 \quad(6)$ & $0(14)$ & $0(26)$ & $O(30)$ & $0(26)$ \\
\hline 5 & Naranjos South (NARS) & M & $8(12)$ & $36(28)$ & $24(38)$ & $52(42)$ & $29(31)$ \\
\hline 6 & Margarita 3 (MAR3) & M & $0 \quad(2)$ & $0 \quad(7)$ & $0(25)$ & $0(27)$ & $4(23)$ \\
\hline 7 & Punta Muerto (PM) & $\mathrm{H}$ & $30(10)$ & 68 (19) & $59(39)$ & $65(63)$ & $35(40)$ \\
\hline 8 & Payardi North (PAYN) & $\mathrm{H}$ & $67(12)$ & $92(40)$ & 69 (45) & $79(72)$ & $77(44)$ \\
\hline 9 & Payardi West (PAYW) & $\mathrm{H}$ & $33 \quad(3)$ & $82(11)$ & $78(46)$ & $85(65)$ & $79(43)$ \\
\hline 10 & Largo Remo 1 (LRE1) & $\mathrm{H}$ & $25 \quad$ (4) & 100 (7) & $65(34)$ & 71 (55) & $80(35)$ \\
\hline 11 & Largo Remo 2 (LRE2) & $\mathrm{H}$ & 22 (9) & $82(39)$ & $55(54)$ & $63(75)$ & $67(46)$ \\
\hline 12 & Galeta Channel (GALC) & $\mathrm{H}$ & $80(10)$ & $81(21)$ & $23(47)$ & $21(78)$ & $11(46)$ \\
\hline
\end{tabular}


Differences among individual years and level of oiling were compared by contrast procedures using BMDP $5 \mathrm{~V}$. To maintain the overall significance level (error rate) at $5 \%$, the significance of contrasts was adjusted using Bonferroni's methods $(\alpha / p$, where $p=$ number of contrasts).

Results of the regeneration experiments were tested using non-parametric Mann-Whitney and $\chi^{2}$ procedures. Relationships between amounts of hydrocarbons and incidence of injuries or growth rates were calculated by the Pearson's Correlation procedure.

\section{RESULTS}

\section{Hydrocarbons}

Oil slicks continued to emerge from mangroves and landfill beneath the refinery, most frequently after heavy rains, but also following very high tides (Table 1). The pattern of this chronic oiling is consistent with that observed immediately after the oil spill (Burns \& Knap 1989, Jackson et al. 1989, Guzmán et al. 1991). From 1987 to 1991, the 6 reefs that were heavily oiled by the spill still had oil over them at a yearly average of 43 to $84 \%$ of the days we made observations, versus only 4 to $31 \%$ of the time over the 2 moderately oiled reefs and 0 to $4 \%$ over reefs that were unoiled in 1986 .

The content of oil in reef sediments over time as determined by GC and UVF analysis is plotted in Fig. 2 (from Burns 1993a). Regression analyses of results of the 2 independent analytical methods plotted against one another demonstrate that trace amounts of oil in reef sediments were still clearly visible 4 yr after the spill $\left(<7 \mu \mathrm{g} \mathrm{g}^{-1}\right.$ dry wt by GC analysis). The change through time in the slope of the regressions shows that the composition of the oil in sediments changed so that the most residual fractions were more fluorescent over time than the oil used for instrument calibration.

Initial collections for chemical analyses of hydrocarbons at heavily oiled reefs were made 4 mo after the spill, but still showed average concentrations per reef of 209 (PAYW) to 406 (GALC) UVF $\mu \mathrm{g}$ oil $\mathrm{g}^{-1} \mathrm{dry}$ weight of sediment (range 79 to 715 ) (Table 2; Burns \& Knap 1989). Oil concentrations in reef sediments decreased subsequently but were still considerable 4 yr after the spill (Table 2). Oil concentrations in tissues of Siderastrea siderea in 1986 varied from 0.1 to $28.8 \mu \mathrm{g}$ oil $\mathrm{mg}^{-1}$ EOM by UVF analysis, and subsequently declined to almost nondetectable levels thereafter (Table 3). During 1989, one unoiled reef (DMA) was contaminated by a relatively fresh fuel oil (Fig. 2), likely originating from ships. This was an isolated incident that did not oil large areas of coastline (Burns 1993b).
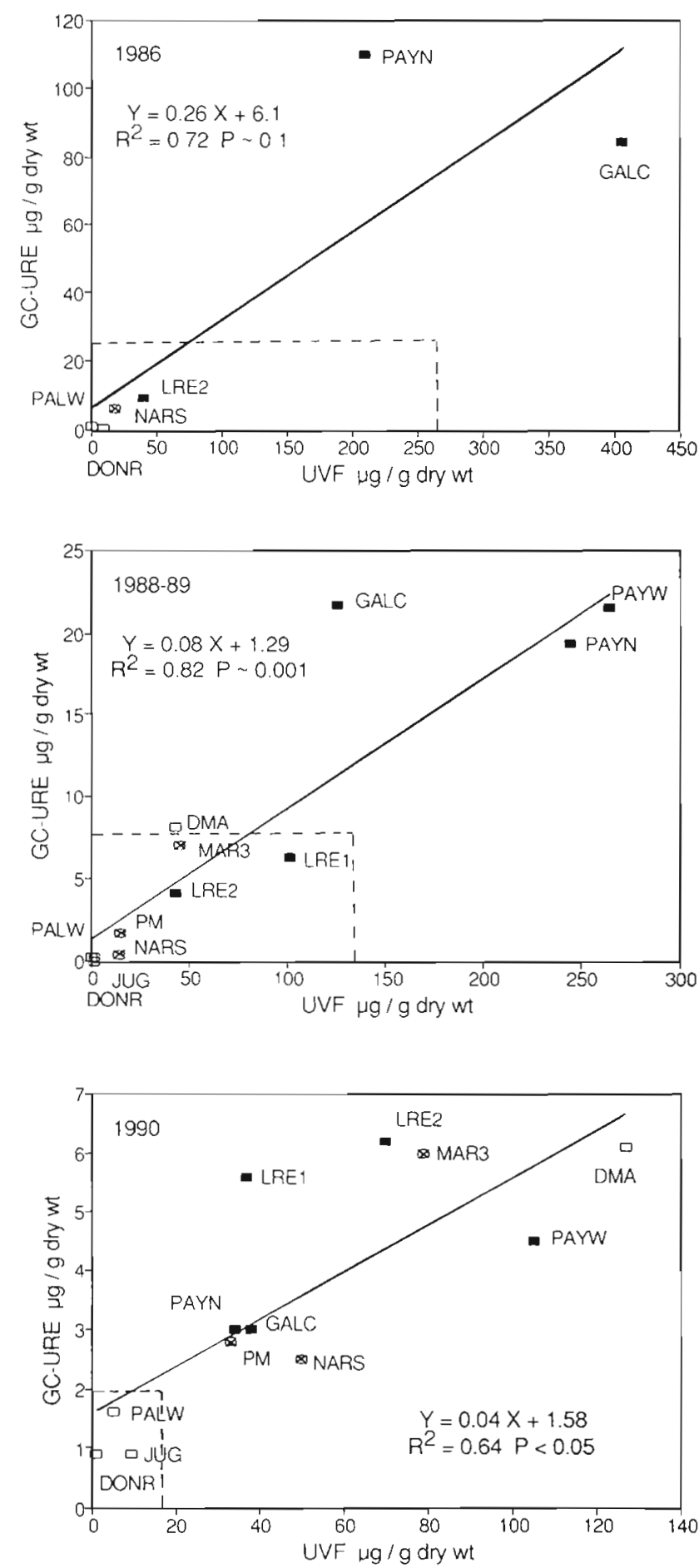

Fig. 2. Regression of oil content in reef sediments estimated by UVF and GC-URE for each year of sampling. Dotted boxes in 1986 and 1988-89 show the range of values of the next sampling year. Dotted box for 1990 shows that the range of 3 uncontaminated, unoiled reefs was clearly distinguishable from the oiled reefs and the contaminated unoiled reef (DMA). Initial visual classifications for severity of oiling:

(更) heavy; ( $\boldsymbol{\otimes}$ ) moderate; ( $\square$ ) no oil (from Burns 1993a). Reefs as in Table 1 
Table 2. Mean (SD) oil content ( $\mu \mathrm{g}$ oil $\mathrm{g}^{-1}$ dry wt) in coral reef sediments by year, by UVF analysis. Samples were done in triplicate. Reefs as in Table 1

\begin{tabular}{|c|c|c|c|}
\hline Reef & 1986 & 1988 & 1990 \\
\hline \multicolumn{4}{|c|}{ Unoiled } \\
\hline JUG & - & $1.7(1.8)$ & $9.5(8.8)$ \\
\hline PALW & $O(0)$ & $1.7(0.3)$ & $5.3(3.4)$ \\
\hline DONR & $10(18)$ & $0.3(0.1)$ & $1.0(0.7)$ \\
\hline $\mathrm{DMA}^{\mathrm{a}}$ & - & $43(12)$ & $127(21)$ \\
\hline \multicolumn{4}{|c|}{ Moderately oiled } \\
\hline MAR3 & - & $54 \quad(67)$ & $79(30)$ \\
\hline NARS & $18(10)$ & $14 \quad(2)$ & $50 \quad(11)$ \\
\hline \multicolumn{4}{|c|}{ Heavily oiled } \\
\hline GALC & $406(206)$ & $126(62)$ & $38(10)$ \\
\hline LRE1 & - & 101 & $37(10)$ \\
\hline LRE2 & $40 \quad(13)$ & 43 (14) & 70 \\
\hline PAYW & - & $264 \quad(123)$ & $105(36)$ \\
\hline PAYN & 209 (93) & $244(137)$ & $34(6)$ \\
\hline PM & - & $15(2)$ & 33 (12) \\
\hline
\end{tabular}

Table 3. Siderastrea siderea. Mean (SD) oil content ( $\mu \mathrm{g}$ oil $\mathrm{mg}^{-1}$ EOM) in tissues by year, by UVF analysis. Triplicate samples. Reefs as in Table 1

\begin{tabular}{|c|c|c|c|}
\hline Reef & 1986 & 1988 & 1990 \\
\hline \multicolumn{4}{|c|}{ Unoiled } \\
\hline JUG & - & $0.0 \quad(0.0)$ & - \\
\hline PALW & $0.1 \quad(0.0)$ & $0.0 \quad(0.0)$ & $0.7 \quad(0.2)$ \\
\hline DONR & $0.1 \quad(0.1)$ & $0.3(0.1)$ & $0.1 \quad(0.0)$ \\
\hline $\mathrm{DMA}^{\mathrm{a}}$ & - & $0.5(0.4)$ & - \\
\hline \multicolumn{4}{|c|}{ Moderately oiled } \\
\hline MAR3 & $0.1(0.0)$ & $0.4(0.1)$ & $0.1 \quad(0.0)$ \\
\hline NARS & $1.2(0.4)$ & $0.3(0.1)$ & $0.1(0.0)$ \\
\hline \multicolumn{4}{|c|}{ Heavily oiled } \\
\hline GALC & $4.3(1.3)$ & $0.2(0.1)$ & $0.1 \quad(0.0)$ \\
\hline LRE 1 & - & $0.6(0.5)$ & - \\
\hline LRE2 & $2.9(0.3)$ & $0.4 \quad(0.2)$ & $0.4(0.0)$ \\
\hline PAYW & - & $0.4(0.2)$ & - \\
\hline PAYN & $28.8(9.0)$ & $0.4(0.2)$ & $0.4 \quad(0.1)$ \\
\hline PM & $0.1(0.7)$ & $0.1(0.1)$ & $0.1 \quad(0.0)$ \\
\hline
\end{tabular}

Table 4. Repeated-measures ANOVA for resuspended sediments and suspended sediments on reefs grouped according to exposure to oil in 1986 (heavily oiled, moderately oiled, unoiled). Data are yearly averages from 1988 to 1991

\begin{tabular}{|llrll|}
\hline Parameter & Factor & $F$ & df & p \\
\hline Resuspended & Oil & 6.17 & 2,8 & 0.02 \\
sediments & Time & 5.83 & 3,24 & 0.003 \\
& Oil $\times$ Time & 1.30 & 6.24 & 0.3 \\
Suspended & Oil & 2.25 & 2,8 & 0.2 \\
sediments & Time & 21.88 & 3,24 & 0.000 \\
& Oil $\times$ Time & 1.67 & 6,24 & 0.2 \\
\hline
\end{tabular}
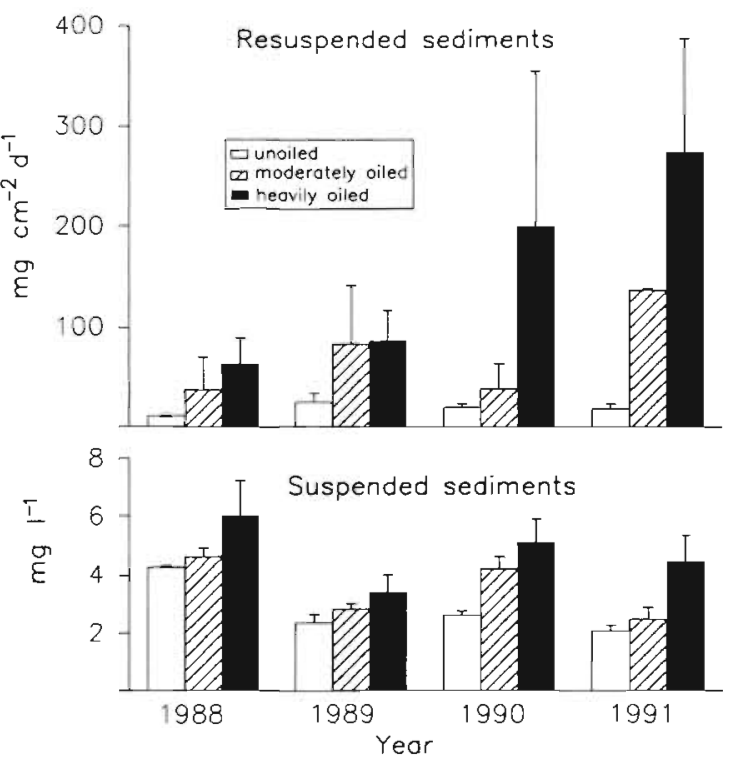

Fig. 3. Yearly average $(+\mathrm{SE})$ of resuspended and suspended sediments in relation to the amount of oiling in 1986. Data recorded from October 1987 to December 1991

\section{Sedimentation}

Yearly averages for resuspended and suspended sediments are shown in Fig. 3 (see Guzmán et al. 1993 for monthly averages). Both measures varied considerably between years but the oil $\times$ year interaction was not significant in either case (Table 4). Amounts of resuspended sediments were significantly higher at heavily oiled reefs and over time. The approximately linear increase in resuspended sediments on heavily oiled versus unoiled reefs was significant over the $4 \mathrm{yr}$ period (repeated-measures ANOVA by contrast; $F=$ $7.87 ; \mathrm{df}=1,8 ; \mathrm{p}=0.02$ ). Suspended sediments decreased slightly over time at unoiled sites but were more variable at oiled reefs.

\section{Injury}

The percentage of recently injured corals was higher in all 3 species examined at heavily oiled compared to unoiled reefs throughout most of the $5 \mathrm{yr}$, but especially during the first year after the oil spill, and then beginning in June 1989 until the final census in March 1991 (Figs. 4 \& 5). Such high incidence of recent injuries had not been reported previously in nearly 20 yr of underwater observations at Galeta and other nearby reefs in Bahía Las Minas. The second period of high levels of injuries corresponded to spills of diesel fuel at the electrical station in Bahia Las Minas. Repeated-measures ANOVAs incorporating oil and depth as factors showed significant effects of the fac- 


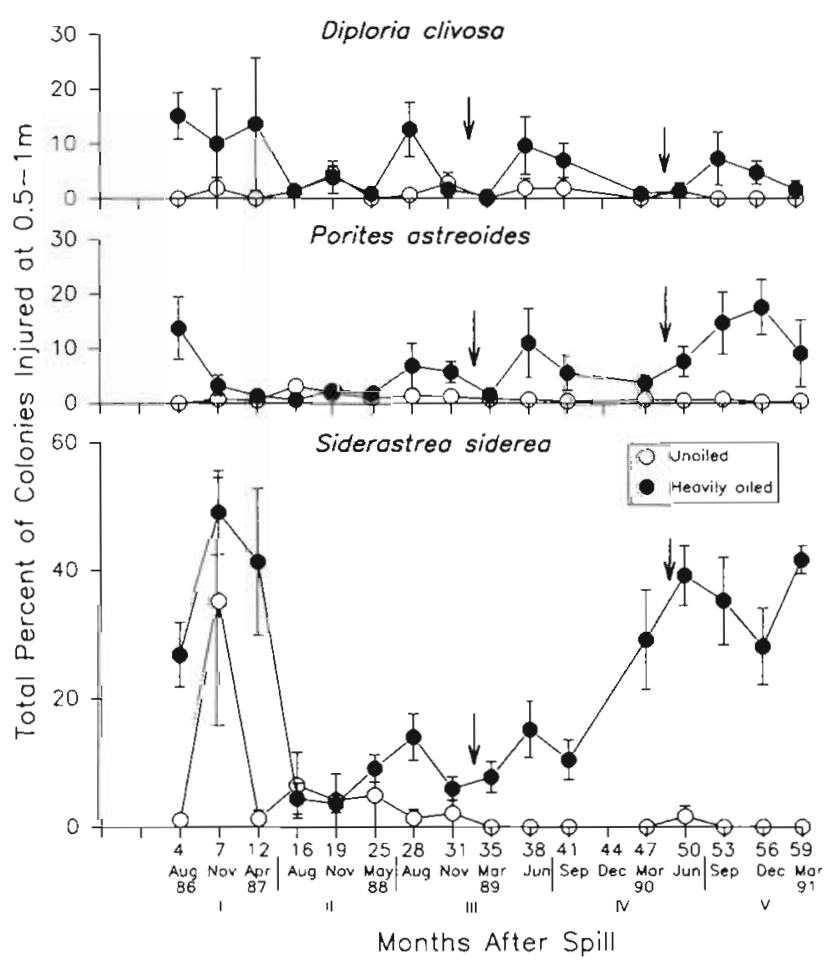

Fig. 4. Changes through time in the percentage ( \pm SE) of recently injured corals at 0.5 to $1 \mathrm{~m}$ depth on 6 heavily oiled and 4 unoiled reefs from August 1986 to March 1991. Arrows indicate the 1988 and 1990 diesel spills (Burns et al. 1993). The vertical lines at the bottom indicate the pooled surveys used for statistical analyses

Table 5. Repeated-measures ANOVA of percent of total injury for 3 coral species

\begin{tabular}{|llrll|}
\hline Species & Factor & $\chi^{2}$ & df & p \\
\hline Siderastrea & Oil & 248.64 & 2 & 0.000 \\
siderea & Depth & 1.55 & 1 & 0.2 \\
& Year & 110.83 & 4 & 0.000 \\
& Oil $\times$ Year & 157.00 & 8 & 0.000 \\
& Oil $\times$ Depth & 0.21 & 2 & 0.9 \\
& Depth $\times$ Year & 15.39 & 4 & 0.004 \\
& Oil $\times$ Depth $\times$ Year & 32.45 & 8 & 0.000 \\
Porites & Oil & 33.57 & 2 & 0.000 \\
astreoides & Depth & 0.02 & 1 & 0.9 \\
& Year & 33.20 & 4 & 0.000 \\
& Oil $\times$ Year & 141.65 & 8 & 0.000 \\
& Oil $\times$ Depth & 0.03 & 2 & 0.9 \\
& Depth $\times$ Year & 1.81 & 4 & 0.8 \\
& Oil x Depth $\times$ Year & 11.17 & 8 & 0.2 \\
Diploria & Oil & 33.51 & 2 & 0.000 \\
clivosa & Depth & 0.17 & 1 & 0.7 \\
& Year & 129.31 & 4 & 0.000 \\
& Oil $\times$ Year & 52.92 & 8 & 0.000 \\
& Oil $\times$ Depth & 0.49 & 2 & 0.8 \\
& Depth $\times$ Year & 25.57 & 4 & 0.000 \\
& Oil $\times$ Depth $\times$ Year & 28.75 & 8 & 0.000 \\
\hline
\end{tabular}

tors oil and year and the oil $\times$ year interaction (groups of years I to $\mathrm{V}$ in Figs. 4 \& 5) for each of the 3 coral species (Table 5). Injuries were similar at both depths for all species.

Contrast analyses between defined time periods (I to V) showed a significant oil effect for all 8 possible comparisons of the 3 coral species. Year and the oil $\times$ year interaction were significant for I-II, I-IV, II-IV, and III-IV for Porites astreoides and I-IV, I-V, II-IV, II-V, and III-V for Siderastrea siderea. These contrasts indicate that the percentage of injured colonies of these species became stabilized between August 1987 and June 1989, although injuries were higher at oiled reefs than unoiled reefs. However, injuries of Diploria clivosa were significantly greater on oiled reefs at all times, and the oil $x$ year interaction was significant in all cases except II-V. Thus the numbers of injured $D$. clivosa varied throughout the study period. For all 3 species the percentage of injured colonies on oiled reefs was as great after $5 \mathrm{yr}$ as a few months after the oil spill.

We used only data from UVF analysis to correlate hydrocarbon concentrations with coral injuries. The amount of hydrocarbons in reef sediments (log-trans-

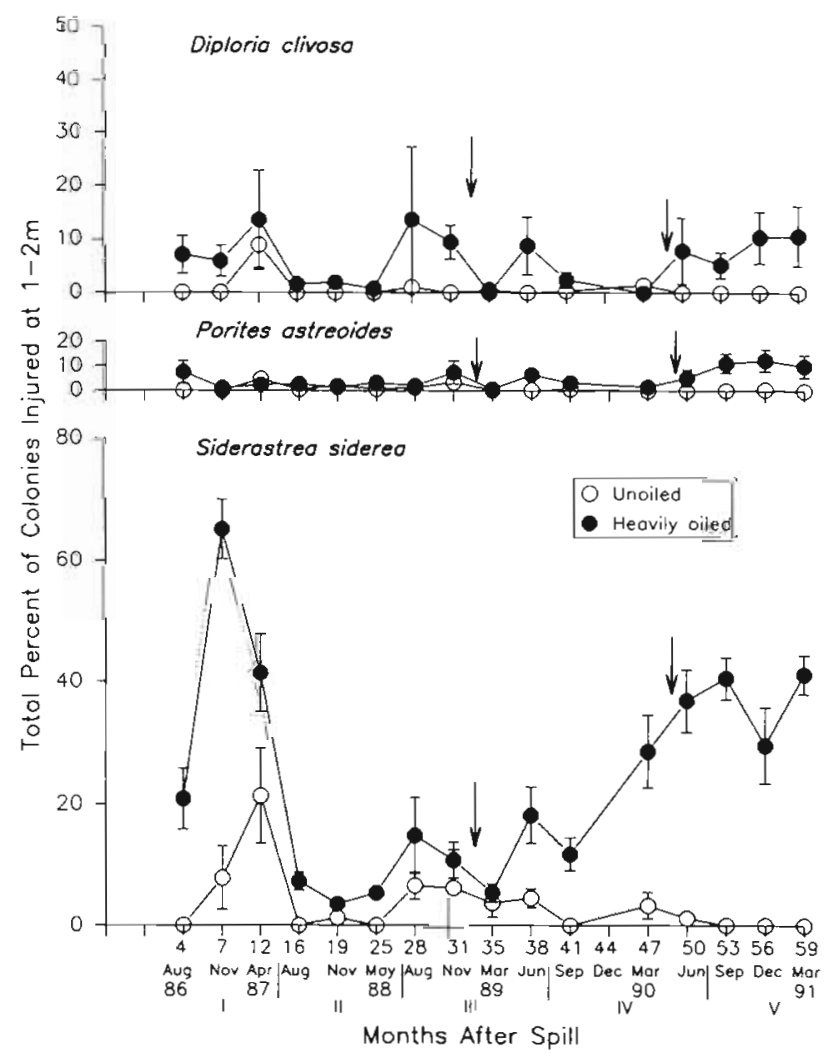

Fig. 5. Changes through time in the percentage of recently injured corals at 1 to $2 \mathrm{~m}$ depth on 6 heavily oiled and 4 unoiled reefs from August 1986 to March 1991. Symbols as in Fig. 4 


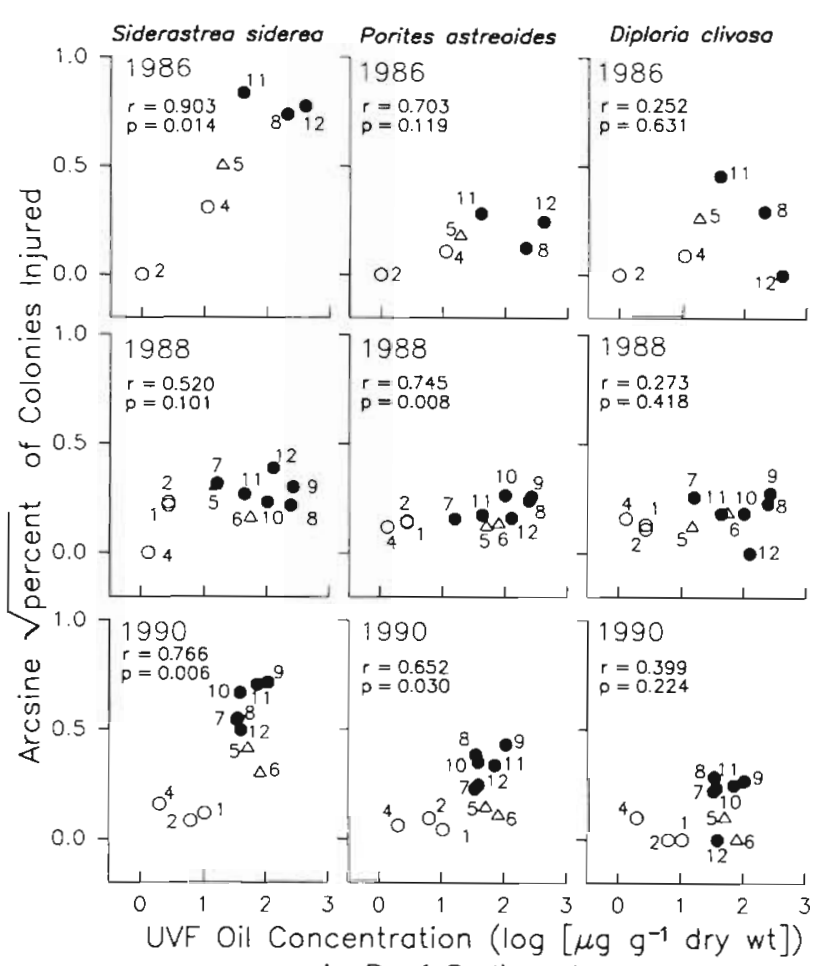

in Reef Sediments

Fig. 6. Siderastrea siderea, Porites astreoides, and Diploria clivosa. Relationship between the percentage of recently injured coral colonies and the concentration of oil in reef sediments in 1986, 1988, and 1990. (•) Reefs heavily oiled in 1986; $(\Delta)$ reefs that were moderately oiled; $(0)$ reefs that were unoiled. Reefs as in Table 1

formed data) was significantly positively correlated with the percentage of injured colonies of Siderastrea siderea (arcsine-transformed data) during 1986 and 1990, but not during 1988 (Fig. 6). In contrast, injury of

Table 6. Percent coral regeneration [mean (SD)] of 4 Caribbean reef corals at oiled and unoiled reefs. First experiment for 12 mo (September 1988 to October 1989); second experiment for 22 mo (November 1990 to September 1992); and reciprocal transplant experiment for 25 mo (August 1990 to September 1992). Mann-Whitney test $_{i} \cdot \mathrm{p}<0.01, \cdot \mathrm{p}<0.05$; ns: not significant

\begin{tabular}{|c|c|c|c|c|c|c|}
\hline \multirow{2}{*}{ Species } & \multicolumn{2}{|c|}{ Expt 1} & \multicolumn{2}{|c|}{ Expt 1} & \multicolumn{2}{|c|}{ Reciprocal transplant } \\
\hline & Oiled & Unoiled & Oiled & Unoiled & Oiled & Unoiled \\
\hline $\begin{array}{c}\text { Siderastrea } \\
\text { siderea }\end{array}$ & $\begin{array}{r}47.0 \\
(10.8)\end{array}$ & $\begin{array}{l}6.1 \cdots \\
(3.0)\end{array}$ & $\begin{array}{r}76.58 \\
(3.5)\end{array}$ & $\begin{array}{l}35.26^{\circ} \\
(10.1)\end{array}$ & $\begin{array}{l}80.5 \\
(4.4)\end{array}$ & $\begin{array}{l}35.9^{\circ} \\
(5.4)\end{array}$ \\
\hline $\begin{array}{l}\text { Porites } \\
\text { astreoides }\end{array}$ & $\begin{array}{r}49.1 \\
(13.0)\end{array}$ & $\begin{array}{l}41.8 \mathrm{~ns} \\
(13.7)\end{array}$ & $\begin{array}{l}91.1 \\
(1.8)\end{array}$ & $\begin{array}{c}59.2 \\
(12.8)\end{array}$ & $\begin{array}{l}83.9 \\
(5.0)\end{array}$ & $\begin{array}{l}50.2^{\circ} \\
(7.5)\end{array}$ \\
\hline $\begin{array}{l}\text { Diploria } \\
\text { clivosa }\end{array}$ & - & - & $\begin{array}{l}89.7 \\
(1.6)\end{array}$ & $\begin{array}{l}77.6^{\circ} \\
(4.9)\end{array}$ & $\begin{array}{l}88.7 \\
(3.5)\end{array}$ & $\begin{array}{l}79.7 \text { ns } \\
(6.4)\end{array}$ \\
\hline $\begin{array}{c}\text { Diplona } \\
\text { strigosa }\end{array}$ & - & - & $\begin{array}{l}79.2 \\
(4.8)\end{array}$ & $\begin{array}{l}56.6^{\circ} \\
(6.1)\end{array}$ & $\begin{array}{r}82.5 \\
(10.0)\end{array}$ & $\begin{array}{l}81.5 \mathrm{~ns} \\
(9.9)\end{array}$ \\
\hline
\end{tabular}

Porites astreoides was significantly correlated with amounts of hydrocarbons in sediments in 1988 and 1990, but not in 1986, whereas Diploria clivosa showed no such clear relationships (Fig. 6). Percent injury for $S$. siderea during 1986 was marginally correlated with the concentration of hydrocarbons in tissues $(\mathrm{n}=8, \mathrm{r}=$ $0.66, p=0.07$ ). Hydrocarbon levels in coral tissues were near nondetectable levels in 1988 and 1990 (Table 3), and showed no relationship with injury ( $\mathrm{n}=$ 12, $\mathrm{r}=-0.13, \mathrm{p}=0.7 ;$ and $\mathrm{n}=8, \mathrm{r}=-0.14, \mathrm{p}=0.7$ respectively).

\section{Regeneration}

The percentage regeneration of lesions for all coral species in each of the experiments is presented in Table 6. In general, Porites astreoides, Diploria clivosa, and $D$. strigosa regenerated faster than Siderastrea siderea. Regeneration was significantly faster at oiled reefs than at unoiled reefs for $S$. siderea in all 3 experiments, in the second and transplant experiment for $P$. astreoides, and in the second experiment for both Diploria species. Results of the transplant experiments demonstrate that more rapid regeneration of corals on oiled reefs was environmentally induced rather than a reflection of some inherent difference between corals from Bahía Las Minas and elsewhere.

\section{Growth}

Growth rates of both Siderastrea siderea and Porites astreoides were lower during the 3 yr after the oil spill than before, regardless of the presence of oil (Fig. 7; see Appendix Table C.4 in Guzmán et al. 1993 for growth data from individual reefs). Growth after the spill declined significantly for $S$. siderea but not for $P$. astreoides at heavily oiled reefs (paired $t$-tests; $t=3.63, \mathrm{df}=5, \mathrm{p}=$ $0.015 ; t=0.52$, df $=5, \mathrm{p}=0.627$, respectively). Repeated-measures ANOVAs were significant for oil and year for $S$. siderea, but again not for $P$. astreoides (Table 7). The oil $x$ year interactions were not significant for either species.

As for injury, we used only UVF data to correlate amounts of hydrocarbons in the environment with coral growth. Levels of hydrocarbons in reef sediments were significantly negatively correlated with growth of Siderastrea siderea and 


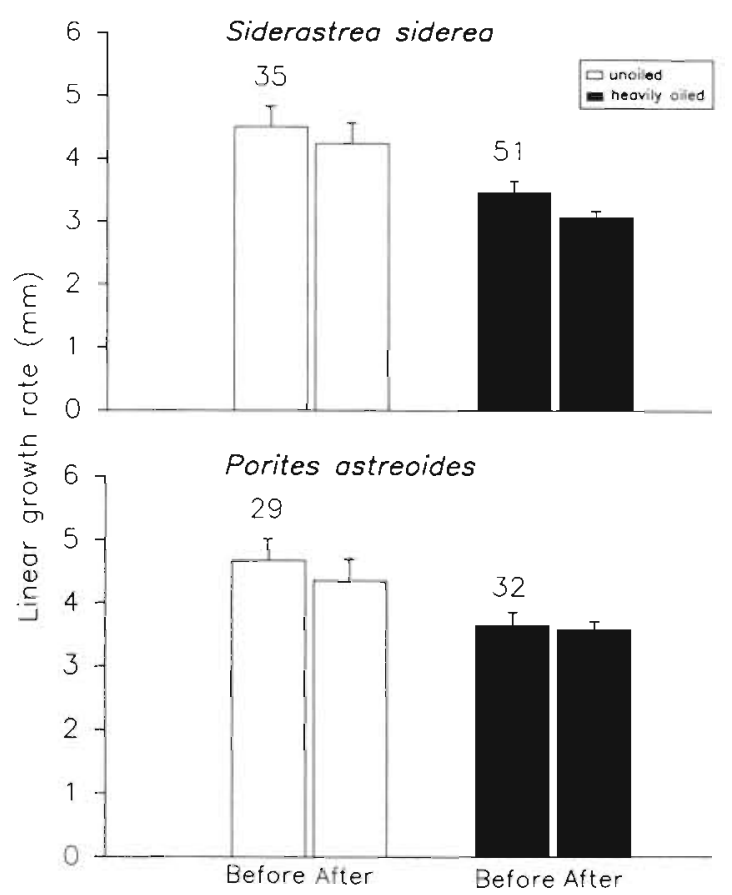

Fig. 7. Siderastrea siderea and Porites astreoides. Average growth ( $\pm \mathrm{SE}$ ) of 2 species of corals 3 yr before the oil spill (1983 to 1985) compared to 3 yr afterwards (1986 to 1988) on 6 reefs that were heavily oiled and 4 reefs that were unoiled in 1986 . Numbers of colonies indicated above bars

Table 7. Repeated-measures ANOVA of growth rates before (1983-85) and after (1986-88) the oil spill for 2 coral species

\begin{tabular}{|llrll|}
\hline Species & Factor & \multicolumn{1}{c}{$F$} & df & $\mathrm{p}$ \\
\hline Siderastrea & Oil & 6.43 & 2,9 & 0.02 \\
siderea & Time & 31.87 & 1,9 & 0.000 \\
& Oil $\times$ Time & 1.55 & 2,9 & 0.3 \\
Porites & Oil & 3.63 & 2,9 & 0.07 \\
astreoides & Time & 2.74 & 1,9 & 0.1 \\
& Oil $\times$ Time & 0.49 & 2,9 & 0.6 \\
\hline
\end{tabular}

Porites astreoides during 1986 and 1988 (Fig. 8). Growth of $S$. siderea was not correlated with amounts of hydrocarbons in coral tissues in 1986 ( $\mathrm{n}=8, \mathrm{r}=$ $-0.30, p=0.48$ ) but was significantly negatively correlated in $1988(\mathrm{n}=10, \mathrm{r}=-0.61, \mathrm{p}=0.047)$.

\section{DISCUSSION}

Initial effects of the oil spill on subtidal corals were severe, including (1) reduction of coverage, abundance, and diversity, (2) greater frequency and size of injured colonies of 3 common species on oiled reefs, and (3) decreased growth rates on oiled.reefs in the

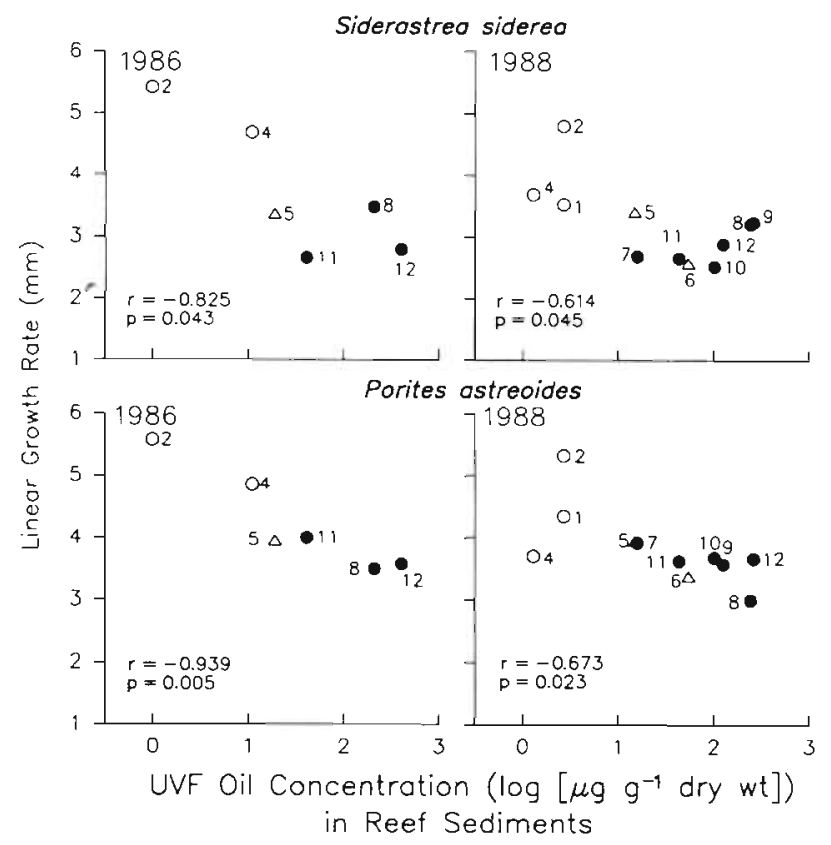

Fig. 8. Siderastrea siderea and Porites astreoides. Relation between linear growth rates and the concentration of oil in reef sediments in 1986 and 1988 . Symbols as in Fig. 6, reefs as in Table 1

year of the spill for 3 out of 4 species examined (Guzmán et al. 1991). Five years later, corals were still chronically and adversely affected by the secondary consequences of the oil spill, as measured by decreased abundance and diversity, increased injuries, and slower growth (Guzmán et al. 1993).

The causes of these effects are complex, but the 2 most important factors are reoiling and sedimentation from the adjacent mangroves. Oil persists in protected tropical coastal environments because of the long time required to flush oil from the fine sediments of mangrove forests, seagrass meadows and porous reef framework (Vandermeulen 1982, Corredor et al. 1990, Guzmán et al. 1991, Burns 1993b, Burns et al. 1993). Thus, 5 yr after the spill, considerable amounts of oil were trapped in mangrove sediments (cores averaged 190000 and $13400 \mu \mathrm{g} \mathrm{g}^{-1} \mathrm{UVF}$ at 0 to 2 and 18 to $20 \mathrm{~cm}$ depth respectively) which still contained high concentrations of relatively toxic fractions (dibenzothiophene, phenanthrene and higher series) (Burns et al. 1993). Likewise, sediments from areas of dead mangroves and seagrass beds were eroded at rates up to several cm per year (Duke \& Pinzon 1993, Marshall et al. 1993, Steger \& Caldwell 1993).

Throughout our study, large amounts of degraded oil and associated sediments continued to be transported out over and onto all the reefs that were oiled in 1986. Moreover, some of the times of increased injury 
(Figs. 4 \& 5) corresponded well to major episodes of sediment erosion and emergence of oil slicks from heavily oiled mangroves (Burns et al. 1993, Steger \& Caldwell 1993). In addition, subsequent smaller spills of diesel fuel may have affected some of the originally oiled reefs, and siltation has increased dramatically throughout Bahía Las Minas since the oil spill (Fig. 3). All of these factors confound the effects of the original oil spill. Nevertheless, it is highly probable that any large oil spill affecting both coral reefs and mangroves would exhibit similarly complex patterns of reoiling and sedimentation associated with the death of mangroves and seagrasses. For example, a large oil spill affecting the Everglades and Florida Bay (USA) would almost certainly result in long-term export of massive amounts of oily sediments onto adjacent reef tracts.

Recent injuries were most frequent for Siderastrea siderea, least for Porites astreoides and variable for Diploria clivosa. A possible explanation lies in the different abilities of the 3 species to reject silt and their growth habits (e.g. flat growth in D. clivosa). Corals subjected to high amounts of oil and sediments clean themselves by continuous secretion of large amounts of mucus (Bak \& Elgershuizen 1976, Lewis \& Price 1976, Rogers 1990). This cleaning process and regeneration of damaged tissues necessarily reduces the amounts of energy and materials available for other functions such as skeletal growth and reproduction (Bak 1983, Bayne 1985, Stearns 1992). For example, lipids are an important component of both mucus and gametes (Benson \& Muscatine 1974, B. L. Willis unpubl. cited in Harrison \& Wallace 1990). Evidence for such tradeoffs in resource allocation comes from the surprisingly rapid regeneration rates of experimentally injured corals on oiled reefs (including most importantly colonies transplanted from unoiled to oiled reefs) in contrast to reductions in growth rates (Figs. 7 \& 8; Guzmán et al. 1991) and fecundity on oiled reefs (Guzmán \& Holst 1993).

Effects of the oil spill on corals in Bahía Las Minas were severe and persistent. After 5 yr, levels of injury were as high as immediately after the spill (Figs. 4 \& 5), further reducing the size, viability and fecundity of surviving colonies (Guzmán et al. 1993, Guzmán \& Holst 1993). Moreover, there has been virtually no recruitment of most formerly dominant coral species (Guzmán et al. 1993), and sublethal effects on vital processes including regeneration, growth, reproduction, and recruitment are likely to persist for decades (Loya \& Rinkevich 1980, Bak 1987, Eakin et al. 1993). Similar patterns were evident for mangrove trees and seagrasses in Bahía Las Minas (Duke \& Pinzon 1993, Garrity \& Levings 1993, Marshall et al. 1993, Steger \& Caldwell 1993). By many standards, our study was long term, but for the once dominant organisms that structure coral reef habitats it was not. Reef communities are just as devastated as they were a few months after the oil spill (Jackson et al. 1989, Guzmán et al. 1991, 1993).

Acknowledgements. E. Weil developed the procedures for measuring injuries and made the initial measurements. L. A. Acosta, M. L. Díaz, C. Guevara, I. Holst, C. E. Jimênez and M. J. Marshall assisted in the field; and E. Grings, I. Holst and C. E. Jiménez helped with the sclerochronology. Hydrocarbon studies were assisted by C. Hackett, D. Jorissen, G. Kananen, J MacPherson, M. Stoelting, J. Tierney, L. Yelle, and numerous students at BBSR. J. D. Brawn, X. Guerra, G. Jácome and $S$. Lao helped with statistics and figures. We thank R. S. Carney, R. E. Dodge, R. H. Green, B. D. Keller, Y. Loya, E. S. Van Vleet, and 3 anomymous reviewers for their advice and reviewing of earlier versions of the manuscript. This study was supported by U.S. Minerals Management Service (Contracts No. 14-12-0001-30355 and 14-12-0001-30393), The Marine Spill Response Corporation (Contract No. 3092PG003), Smithsonian Tropical Research Institute and the Smithsonian Institution Environmental Sciences Program. Contribution No. 1335 of the Bermuda Biological Station for Research.

\section{LITERATURE CITED}

Bak, R. P. M. (1983). Neoplasia, regeneration and growth in the reef-building coral Acropora palmata. Mar. Biol. 77: $221-227$

Bak, R. P. M. (1987). Effects of chronic oil pollution on a Caribbean coral reef. Mar. Pollut. Bull. 18: 534-539

Bak, R. P. M., Brouns, J. J., Heys, F. M. (1977). Regeneration and aspects of spatial competition in the scleractinian corals Agaricia agaricites and Montastrea annularis. Proc. 3rd int. coral Reef Symp. 2: 143-148

Bak, R. P. M., Elgershuizen, J. H. B. W. (1976). Patterns of oilsediment rejection in corals. Mar. Biol. 37: 105-113

Bak, R. P. M., Steward-van Es, Y (1980). Regeneration of superficial damage in the scleractinian corals Agaricia agaricites, A. purpurea and Porites astreoides. Bull. mar. Sci. 30: $883-887$

Bayne, B. L. (1985). Ecological consequences of stress. In: Bayne, B. L., Brown, D. A., Burns, K., Dixon, D. R., Ivanivici, A., Livingstone, D. R., Lowe, D. M., Moore, M. N., Stebbing, A. R. D., Widdows, J. (eds.) The effects of stress and pollution on marine animals. Praeger Publisher, New York, p. 141-157

Benson, A. A., Muscatine, L. (1974). Wax in coral mucus: energy transfer from corals to reef fishes. Limnol. Oceanogr 19: 810-814

Burns, K. A. (1993a). Analytical methods used in oil spill stud. ies. Mar. Pollut. Bull. 26: 68-72

Burns, K. A. (1993b). Hydrocarbon chemistry. In: Keller, B. D., Jackson, J. B. C. (eds.) Long-term assesment of the oil spill at Bahía Las Minas, Panama, synthesis report, vol. II, technical report U.S. Department of the Interior, Minerals Management Service, Gulf of Mexico OCS Region, New Orleans, p. 51-130

Burns, K. A., Knap، A. H. (1989). The Bahía Las Minas oil spill: hydrocarbon uptake by reef building corals. Mar. Pollut. Bull. 20: $391-398$

Burns, K. A., Garrity, S., Joriseen, D., MacPherson, J., Stoelting, M., Tierney, J., Yelle, L. (1993). The Galeta oil spill II: 
Unexpected persistence of oil trapped in mangrove sediments. Estuar. coast. Shelf Sci. (in press)

Corredor, J. E., Morell, J. M., del Castillo, C. E. (1990). Persistence of spilled crude oil in a tropical intertidal environment. Mar. Pollut. Bull. 21: 385-388

Cortés, J., Risk, M. J. (1985). A reef under siltation stress: Cahuita, Costa Rica. Bull. mar. Sci. 36: 339-355

Dixon, W. J., Brown, M. B., Engelman, L., Jennick, R. I. (eds.) (1990). BMDP statistical software manual, vols. 1 \& 2 . Univ. California Press, Berkeley

Duke, N. C. Pinzón, Z. S. (1993). Mangrove forests. In: Keller, B. D., Jackson, J. B. C. (eds.) Long-term assessment of the oil spill at Bahía Las Minas, Panama, synthesis report, vol. II, technical report U.S. Department of the Interior, Minerals Management Service, Gulf of Mexico OCS Region, New Orleans, p. 447-533

Eakin, C. M., Feingold, J. S., Glynn, P. W. (1993). Oil refinery impacts on coral reef communities in Aruba, N.A. Global aspects of coral reefs: health, hazards and history. Rosenstiel School of Marine and Atmospheric Science, University of Miami, Coral Gables, p. 43-49

Garrity, S. D., Levings, S. C. (1993). Patterns of damage and recovery from a major oil spill: the mangrove fringe and the epibiota of mangrove roots. In: Keller, B. D., Jackson, J. B. C. (eds.) Long-term assessment of the oil spill at Bahía Las Minas, Panama, synthesis report, vol. II, technical report U.S. Department of the Interior, Minerals Management Service, Gulf of Mexico OCS Region, New Orleans, p. $535-792$

Green, R. H. (1979). Sampling design and statistical methods for environmental biologists. John Wiley \& Sons, New York

Guzmán, H. M., Holst, I. (1993). Effects of chronic oil-sediment pollution on the reproduction of the Caribbean reef coral Siderastrea siderea. Mar. Pollut. Bull. 26: 276-282

Guzmán, H. M., Jackson, J. B. C., Holst, I. (1993). Changes and recovery of subtidal reef corals. In: Keller, B. D., Jackson, J. B. C. (eds.) Long-term assessment of the oil spill at Bahía Las Minas, Panama, synthesis report, vol. II, technical report U.S. Department of the Interior, Minerals Management Service, Gulf of Mexico OCS Region, New Orleans, p. 361-446

Guzmán, H. M., Jackson, J. B. C., Weil, E. (1991). Short-term ecological consequences of a major oil spill on Panamanian subtidal reef corals. Coral Reefs 10: $1-12$

Hand, D. J., Taylor, C. C. (1987). Multivariate analysis of variance and repeated measures. Chapman and Hall, London

Harrison, P. L., Wallace, C. D. (1990). Reproduction, dispersal, and recruitment of scleractinian corals. In: Dubinsky, $Z$. (ed.) Coral reefs. Elsevier, Amsterdam, p. 133-208

IOC/UNEP/IAEA. (1991). Determination of petroleum hydrocarbons in marine sediments. In: Burns, K. A. (ed.) Manual and guides No. 20, Rev. 1. International Atomic Energy Agency, Monaco, p. 101

Jackson, J. B. C. (1983). Biological determinants of present and past sessile animal distributions. In: Tevesz, M. J. S.,

This article was submitted to the editor
McCall, P. L. (eds.) Biotic interactions in Recent and fossil benthic communities. Plenum Press, New York, p. 39-120 Jackson, J. B. C., Cubit, J. D., Keller, B. D., Batista, V., Burns, K., Caffey, H. M., Caldwell, R. L., Garrity, S. D., Getter, C. D., Gonzalez, C., Guzmán, H. M. Kaufmann, K. W. Knap, A. H., Levings, S. C., Marshall, M. J., Steger, R., Thompson, R. C., Weil, E. (1989). Ecological effects of a major oil spill on Panamanian coastal marine communities. Science 243: 37-44

Lewis, J. B., Price, W. S. (1976). Patterns of ciliary currents in Atlantic reef corals and their functional significance J. Zool., Lond. 178: 77-89

Loya, Y (1976). Recolonization of Red Sea corals affected by natural catastrophes and man-made perturbations. Ecology 57: $278-289$

Loya, Y., Rinkevich, B. (1980). Effects of oil pollution on coral reef communities. Mar. Ecol. Prog. Ser. 3: 167-180

Marshall, M. J., Batista, V., Matias, D. (1993). Impact of the 1986 Bahía Las Minas, Panama, oil spill on plants and animals in seagrass communities. In: Keller, B. D., Jackson, J. B. C. (eds.) Long-term assessment of the oil spill at Bahía Las Minas, Panama, synthesis report, vol. II, technical report U.S. Department of the Interior, Minerals Management Service, Gulf of Mexico OCS Region, New Orleans, p. $793-832$

Palumbi, S. R., Jackson, J. B. C. (1982). Ecology of cryptic coral reef communities. II. Recovery from small disturbance events by encrusting Bryozoa: the influence of 'host' species and lesion size. J. exp. mar. Biol. Ecol. 64: $103-115$

Rogers, C. S. (1990). Responses of coral reefs and reef organisms to sedimentation. Mar. Ecol. Prog. Ser. 62: 185-202

Schluchter, M. D. (1990). Unbalanced repeated measures models with structured convariance matrices. In: Dixon W. J. (ed.) BMDP statistical software manual, Vol. 2. University of California, Berkeley, p. 1207-1244

Stearns, S. C. (1992). The evolution of life histories. Oxford Univ. Press, Oxford

Steger, R., Caldwell, R. (1993). Reef flat stomatopods. In Keller, B. D., Jackson, J. B. C. (eds.) Long-term assessment of the oil spill at Bahía Las Minas, Panama, synthesis report, vol. II, technical report U.S. Department of the Interior, Minerals Management Service, Gulf of Mexico OCS Region, New Orleans, p. 293-359

Tomascik, T., Sander, F. (1985). Effects of eutrophication on reef-building corals. I. Growth rate of the reef-building coral Montastrea annularis. Mar. Biol. 87: 143-155

Underwood, A. J. (1981). Techniques of analysis of variance in experimental marine biology and ecology. Oceanogr. mar. Biol. A. Rev. 19: 513-605

Vandermeulen, J. H. (1982). Some conclusions regarding long-term biological effects of some major oil spills. Phil. Trans. R. Soc. Lond. B 297: 335-351

Wahle, C. M. (1983). The role of age, size and injury in sexual reproduction among Jamaican gorgonians. Am. Zool. 23 961

Manuscript first received: June 7, 1993

Revised version accepted: October 22, 1993 